advantages to the community and to the profession, provided decisions are based on knowledge and good judgement rather than on political expediency, and provided the incentives to personal efficiency are maintained and the hazards of uniformity are avoided.

\section{REFERENCES}

${ }^{1}$ Mellanby, E., The State and Medical Research, 1939. Edinburgh, Oliver and Boyd.

${ }^{2}$ Rashdall, H., Universities of Europe in the Middle Ages, 1895. Oxford, Clarendon Press.

3 Statutes of the University of Padua, 1589.

* Adelmann, H. B., The Embryological Treatises of Hieronymus Fabricius of Aquapendente, 1942. New York, Cornell University Press.

O'Malley, C. D., Andrea Vesalius of Brussels, 1514-1564, 1964. Berkely, University of California Press.

${ }^{6}$ Underwood, E. A., Annals of Science, 1963, 19, 1.

Whitteridge, G., British Medical fournal, 1966, $2,7$.

Report of the Royal Commission on Medical Education, 1965-68, 1968, Cmnd. 3569. London, H.M.S.O.
9 Flexner, A., Medical Education in Europe. Report to the Carnegie Foundation, 1912. New York, Carnegie Foundation.

Medical Education, fournal of the American Medical Association, 1968, 206, 1988.

1 Duff, S. L., and Fish, D. G., Canadian Medical Association, 1967, 96,

12 Fish, D. G., Canadian Medical Association fournal, 1967, 97, 1587.

13 Christie, R. V., Fournal of Medical Education, 1963, 38, 662.

14 University Grants Committee, University Development 1957-1962, 1963. London, H.M.S.O.

15 Seely, J. F., McGill Medical fournal, 1961, 30, 10.

${ }^{16}$ Ministry of Health, First Report of the Foint Working Party on the Organization of Medical Work in Hospitals, 1967. London, H.M.S.O.

1) Scottish Home and Health Department, Organization of Medical Work in the Hospital Service in Scotland, 1967. Edinburgh,

18 Miller, H., Lancet, 1966, 2, 647.

1. Report on Teaching Facilities and Student Amenities in Scottish Hospitals. Royal College of Physicians, Edinburgh, 1957.

${ }^{20}$ Ministry of Health, Report of the Committee of Enquiry into the Cost of the National Health Service, 1956,. Cmnd. 9663. London,
H.M.S.O.

\title{
Epidemiology of Urinary Tract Diseases in General Practice
}

\author{
J. STEENSBERG,* M.D. ; E. D. BARTELS,† M.D. ; H. BAY-NIELSEN,ł M.D. \\ E. FANØE,§ M.D. ; T. HEDE, $\|$ M.D.
}

British Medical fournal, 1969, 4, 390-394

\begin{abstract}
Cummary: During a one-year morbidity survey of $\checkmark$ urinary tract diseases in general practice 741 cases were diagnosed. Only about half of all the patients with symptoms of urinary tract infection had significant bacteriuria. In young women urinary tract infections and symptoms from the urinary tract without bacteriuria-in particular urethritis-were found to predominate. In middle-aged women, the urinary tract symptoms were ascribed increasingly to genital prolapse, while incidence of urolithiasis was the highest in any group, and urinary tract infections became less frequent. The prevalence of urinary tract infection showed another increase in elderly women, and recurrent/chronic pyelonephritis, which occurs with a steadily increasing prevalence throughout all age groups, became common.

In younger male urological patients diseases with symptoms of urinary tract infection without bacteriuria were predominant, whereas prostatitis and urinary tract infections were less frequent. In middle-aged men, urolithiasis was especially frequent, while an increasing proportion of elderly men had prostatic hypertrophy, urinary tract infections, and recurrent/chronic pyelonephritis.
\end{abstract}

\section{Introduction}

Information available on the incidence of renal and urinary tract diseases in the general population is derived mainly from hospital statistics. It is, however, of greater importance to collect morbidity data from general practice, because most urinary tract diseases run such a mild course that the patients are not referred to hospital. In countries where the public health system is based on definite groups of people being registered with the same doctor for reasonable periods of time,

* Medical Officer, the National Health Service of Denmark, Copenhagen. t Chief Physician, Department of Medicine B, Glostrup Hospital, Denmark.

¥Assistant Chief Surgeon, Department of Surgery A, Glostrup Hospital, Denmark.

$\$$ General Practitioner, Rødovre, Denmark.

|| General Practitioner, Søborg, Denmark. as, for example, in England and Denmark, the prerequisites of such studies are present. Nevertheless, very few studies on morbidity, dealing in particular with renal and urinary tract diseases, have been published (Fry et al., 1962 ; Loudon and Greenhalgh, 1962 ; Gallagher et al., 1965; Mond et al., 1965 ; Sourander, 1966).

The object of the present study is to clarify the prevalence of urinary tract disorders in general practice.

\section{Material and Methods}

The population included in this study is that of a typical suburb of Copenhagen. Adults are recorded separately by the health insurance funds, and, on the basis of their panels, the material studied was derived from a population group comprising 22,000 adults. About $53 \%$ of the population are females, the age distribution for the sexes being almost equal. The 10 doctors participating in the study, ${ }^{1}$ representing eight general practices, had on an average 2,200 adult patients each, though the size and composition of the individual practices varied considerably.

The morbidity rates are recorded as period prevalence rates per year. We ascertained the number of adults (16 years of age and above) who during the survey period from 1 November 1964 to 31 October 1965 consulted their family doctor once or more, presenting symptoms of renal and urinary tract disease. Patients with gonorrhoea are excluded from the material. A total of 796 patients (606 women $(76 \%)$ and $190 \mathrm{men}$ ) were recorded. More detailed examinations showed that 55 of these patients had no urinary tract disease.

A special system was contrived for establishing the diagnosis, classified into three groups of urinary tract infections and related diseases, according to the results of the bacteriological examination of the urine: definite urinary tract infection (more than 50,000 colonies $/ \mathrm{ml}$.); doubtful growth of bacteria $(2,000-50,000 \mathrm{col} . / \mathrm{ml}$.$) ; and no growth of bacteria (<2,000$ \footnotetext{
${ }^{1}$ Participating General Practitioners : Inger Berthelsen, P. Berthelsen, E.
Fanøe, F. Gam, T. Hede, A. E. Pallesen, Inger Smed Pedersen, K. Smed Pedersen, P. Simonsen, and K. Zachrau.
} 
col./ml.). The value of more than $50,000 \mathrm{col} . / \mathrm{ml}$. to indicate significant bacteriuria was chosen after considering limits suggested by other authors (Merritt et al., 1958 ; Effersøe and Jensen, 1963). The diagnoses are defined in Table I. Data were transferred direct from the special examination schedule to punch cards for electronic processing.

TABLE I.-Diagnoses Made in Urinary Tract Infections and Related Diseases

\begin{tabular}{|c|c|}
\hline Diagnosis & Definition \\
\hline Cystitis/urethritis & Symptoms from lower urinary tract \\
\hline Pyelonephritis/pyelitis & $\begin{array}{l}\text { (1) Raised serum creatinine value and symptoms } \\
\text { of infection } \\
\text { (2) Typical abnormal findings at intravenous } \\
\text { pyelography and symptoms of infection } \\
\text { (3) Backache combined with at least two of the } \\
\text { following symptoms: fever, leucocyturia, } \\
\text { proteinuria, anaemia, hypersedimentation }\end{array}$ \\
\hline Cystopyelitis & $\begin{array}{l}\text { Pyelonephritis/pyelitis and symptoms from } \\
\text { lower urinary tract }\end{array}$ \\
\hline
\end{tabular}

In $86 \%$ of the women the urine specimens were collected by means of sterile disposable catheters. In the remaining women and in the men midstream specimens were collected, a well-established technique being used. Microscopy was carried out on centrifuged urine, the magnification being about $\times 400$. The urine for bacteriological study was stored at $4^{\circ} \mathrm{C}$., and the cultures were planted within 48 hours. A quantitative technique was used-a calibrated platinum loop $(0.01 \mathrm{ml}$.), spreading with a spatula on a blood agar plate, and counting the colonies after storage for 24 hours at $37^{\circ} \mathrm{C}$. Only one bacteriological examination was made before treatment. In addition the haemoglobin content of the blood, the erythrocyte sedimentation rate, and the serum creatinine concentration were determined, blood pressure was recorded, and in some cases intravenous pyelography was carried out.

The extent to which the persons recorded had undergone a thorough examination is shown in Table II. Those who were not examined thoroughly did not differ from those whose examination was comprehensive.

TABLE II.-Investigations Made in 796 Registered Persons

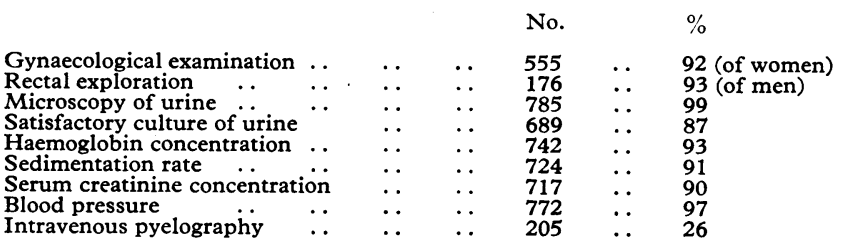

Eleven per cent. of the women and $34 \%$ of the men with urinary tract disease were referred to hospital, mainly to surgical units.

\section{Results}

The conditions seen in the patients studied from a diagnostic viewpoint are given in Table III.

TABLE III.-Diagnoses in 741 Patients with Urinary Tract Disease

\begin{tabular}{|c|c|c|c|c|}
\hline \multirow{2}{*}{ Diagnoses } & \multicolumn{2}{|c|}{ Females } & \multicolumn{2}{|c|}{ Males } \\
\hline & No. & $\%$ & No. & $\%$ \\
\hline $\begin{array}{l}\text { Bacteriologically verified infection } \\
\text { ( }>50,000 \text { col./ml.) } \ldots \\
\text { Symptoms of infection with insigni- } \\
\text { ficant bacteriuria }(2,000-50,000 \text { col./ } \\
\text { ml.) .. } \\
\text { Symptoms of infection without bac- } \\
\text { teriuria }(<2,000 \text { col./ml.) } \\
\text { Other urinary tract diseases exclu- } \\
\text { sively } \quad . . \\
\text {. }\end{array}$ & $\begin{array}{r}60 \\
131 \\
157 \\
\end{array}$ & $\begin{array}{l}10 \\
23 \\
28\end{array}$ & $\begin{array}{r}3 \\
24 \\
109\end{array}$ & $\begin{array}{r}2 \\
14 \\
64\end{array}$ \\
\hline Total $\ldots$ & 571 & 100 & 170 & 100 \\
\hline
\end{tabular}

\section{Definite Infection}

In $223(54 \%)$ of the 414 women with symptoms of urinary tract infection and in $34(56 \%)$ of the 61 men with symptoms, the suspected urinary tract infection was verified by bacteriological examination of the urine. The age distribution appears in Table IV. This table and Fig. 1 show, in addition, the age-

TABLE IV.-Prevalence of Urinary Tract Infection

\begin{tabular}{|c|c|c|c|c|c|c|}
\hline \multirow[t]{2}{*}{$\begin{array}{c}\text { Age in } \\
\text { years }\end{array}$} & \multicolumn{2}{|c|}{ No. of patients } & \multirow{2}{*}{$\begin{array}{l}\text { Age distribution } \\
\text { of population in } \\
\text { suburban } \\
\text { penhagen } \\
(\%)\end{array}$} & \multirow[t]{2}{*}{$\begin{array}{l}\text { Computed age } \\
\text { distribution of } \\
11,000 \text { per- } \\
\text { sons (No.) }\end{array}$} & \multicolumn{2}{|c|}{$\begin{array}{c}\text { Computed No. } \\
\text { of patients per } \\
1,000 \text { persons } \\
\text { per year }\end{array}$} \\
\hline & Females & Males & & & Females & Males \\
\hline $\begin{array}{l}16-19 \\
20-29 \\
30-39 \\
40-49 \\
50-59 \\
60-69 \\
70-\end{array}$ & $\begin{array}{l}18 \\
65 \\
54 \\
34 \\
17 \\
20 \\
15\end{array}$ & $\begin{array}{l}0 \\
2 \\
6 \\
8 \\
3 \\
6 \\
9\end{array}$ & $\begin{array}{c}11 \cdot 4^{*} \\
22.5 \\
22.5 \\
19.6 \\
12.6 \\
6.9 \\
4.5\end{array}$ & $\begin{array}{r}1,250 \\
2,480 \\
2,480 \\
2,160 \\
1,390 \\
760 \\
500\end{array}$ & $\begin{array}{l}14 \\
26 \\
22 \\
16 \\
12 \\
26 \\
30\end{array}$ & $\begin{array}{r}0 \\
1 \\
2 \\
4 \\
2 \\
8 \\
18\end{array}$ \\
\hline $\begin{array}{l}\text { Total } \\
\text { Average }\end{array}$ & $\underline{223}$ & 34 & 100 & $(11,020)$ & $\overline{20}$ & $\overline{3}$ \\
\hline
\end{tabular}

* The first age group is $15-19$ years.

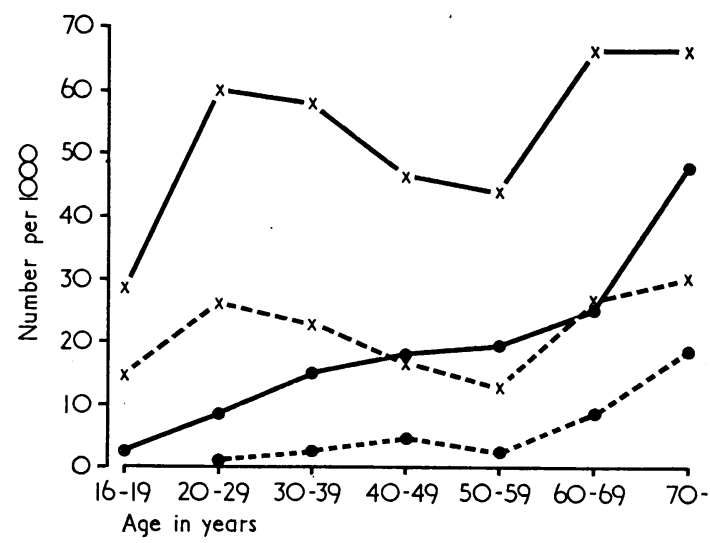

Fig. 1.-Prevalence of urinary tract disease. $\times-\times$, Females with urinary tract disease. $\times \ldots \times$, Females with urinary tract infection. Males with urinary tract disease. tract disease. -.. Mal, Malection.

specific prevalence rates calculated. The average prevalence is six to seven times as high in women as in men. A more detailed analysis shows that the age-specific prevalence rates in women with acute infection have the same distribution as for all infected women, whereas the prevalence of recurrent or chronic infections increases steadily with age. On average the frequency of acute infections in women is twice that of recurrent/chronic infections (13 and 7 per 1,000 per year), and infections confined to the lower urinary tract (cystitis) occur twice as frequently as more widespread infections (pyelonephritis or cystopyelitis), with average prevalence rates of 13 and 7 per 1,000 per year. Also in men the average prevalence rate of acute urinary tract infection is twice as high as that of recurrent/chronic cases.

TABLE V.-Prevalence in Women of Urinary Tract Infection According to Marital Status

\begin{tabular}{l|c|c|c|c}
\hline & $\begin{array}{c}\text { No. of } \\
\text { patients }\end{array}$ & $\begin{array}{c}\text { Percentage of fe- } \\
\text { male population } \\
\text { in suburban Co- } \\
\text { penhagen }\end{array}$ & $\begin{array}{c}\text { Computed num- } \\
\text { ber of 11,000 } \\
\text { females }\end{array}$ & $\begin{array}{l}\text { Computed No. of } \\
\text { women with urin- } \\
\text { ary tract infection } \\
\text { per 1,000 females } \\
\text { per year }\end{array}$ \\
\hline $\begin{array}{l}\text { Married } \\
\text { Unmarried }\end{array}$ & 155 & $67 \cdot 2$ & 7,400 & 21 \\
$\begin{array}{l}\text { Divorced } \\
\text { Judicially } \\
\text { separated }\end{array}$ & 17 & $21 \cdot 4$ & 2,360 & 15 \\
Widows & 13 & $4 \cdot 3$ & 470 & 36 \\
\hline Total & 13 & $6 \cdot 0$ & 110 & 27 \\
Average & 223 & 100 & $(11,030)$ & 20 \\
\hline
\end{tabular}


The distribution of women with urinary tract infections according to marital status is shown in Table V. The prevalence rates are lower in single women and higher in divorced and judicially separated women. In men the highest prevalence rates were found in widowers, presumably because of their high age.

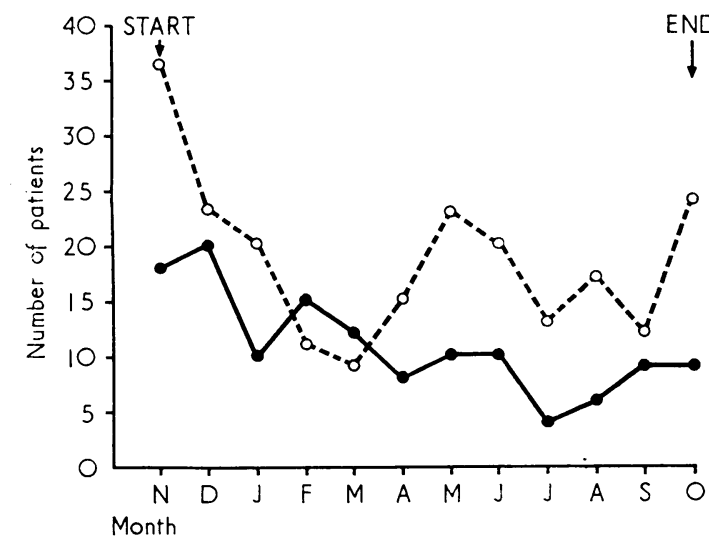

FIG. 2.-Seasonal variation in registration of women. , 131 cases with symptoms of infection without bacteriuria.

Fig. 2 shows the number of women with bacteriologically verified urinary tract infection recorded within each calendar month from November 1964. Previous histories seem to indicate that almost two-thirds of women with urinary tract infection had been infected earlier, though the actual figurebecause of faulty diagnosis at previous examinations-must be somewhat lower. Nine per cent. of the women were pregnant at the time of examination (in the age group 15-49 years, $11 \%$ ), $28 \%$ were past the menopause, $22 \%$ had never been pregnant, and $21 \%$ had previously undergone gynaecological surgery.

In both women and men the symptoms most often encountered were frequency of micturition, dysuria, imperative micturition, and cloudy or foul urine ; while the men complained of weak stream and prolonged micturition more often than the women. Clinical examination in $11 \%$ of the women showed tenderness in the kidney region. A further review of these 25 cases shows that this finding may indicate that the patient suffers from a more serious urinary tract infection. Genital prolapse was found in $11 \%$ of the 200 women examined gynaecologically. Prostatic enlargement was present in $27 \%$ of the 33 men in whom rectal exploration was carried out.

In $87 \%$ of the women with infection the urine specimens were taken by means of a catheter. Twenty-five per cent. of the women and $29 \%$ of the men had proteinuria according to a qualitative examination. Urine microscopy revealed leucocyturia in $77 \%$ of both women and men (5 or more leucocytes per visual field), whereas $28 \%$ of the women and $44 \%$ of the men had haematuria ( 5 or more erythrocytes per visual field).

Bacteriological examination of the urine of the women showed Escherichia coli in $70 \%$, while the next most frequent organism was Staphylococcus saprophyticus in $14 \%$ of the patients. Seventeen women $(8 \%)$ had mixed infection. In 25 of the 31 women with Staph. saprophyticus in the urine this organism was found in pure culture, and none of these patients was over 60 years of age. Ninety per cent. of the women with growth of this organism had leucocyturia and $55 \%$ had haematuria.

In half of the infected men growth of $E$. coli was found, in $27 \%$ Streptococcus faecalis, and $15 \%$ had mixed infection. Of 21 men with conditions predisposing to urinary tract infection $71 \%$ had bacteria other than $E$. coli in their urine.

In both sexes two-thirds of the infections were interpreted as acute. The infections in two-thirds of the women and in one-half of the men were thought to be confined to the lower urinary tract. During the period of survey, only $11 \%$ of the definitely infected women, as against $59 \%$ of the infected men, were referred to hospital.

\section{Symptoms without Bacteriuria}

In $131(32 \%)$ of the 414 women with symptoms of urinary tract infection no bacterial growth could be found in the urine $(<2,000 \mathrm{col} . / \mathrm{ml}$.). Table VI shows the age distribution and

TABLE VI.-Prevalence in Women of Symptoms of Urinary Tract Infection Without Bacteriuria and Recurrent/Chronic Pyelonephritis or Cystopyelitis

\begin{tabular}{|c|c|c|c|c|c|c|c|c|}
\hline \multirow[b]{2}{*}{$\begin{array}{l}\text { Age in } \\
\text { years }\end{array}$} & \multicolumn{4}{|c|}{$\begin{array}{l}\text { Symptoms of urinary tract in- } \\
\text { fection without bacteriuria* }\end{array}$} & \multicolumn{4}{|c|}{$\begin{array}{l}\text { Recurrent/chronic pyelonephri } \\
\text { tis or cystopyelitist }\end{array}$} \\
\hline & \multicolumn{2}{|c|}{ No. of patients } & \multicolumn{2}{|c|}{$\begin{array}{c}\text { Computed No. } \\
\text { of patients per } \\
1,000 \text { females } \\
\text { per year }\end{array}$} & \multicolumn{2}{|c|}{ No. of patients } & \multicolumn{2}{|c|}{$\begin{array}{c}\text { Computed No. } \\
\text { of patients per } \\
1,000 \text { females } \\
\text { per year }\end{array}$} \\
\hline $\begin{array}{l}16-19 \\
20-29 \\
30-39 \\
40-49 \\
50-59 \\
60-69 \\
70-\end{array}$ & $\begin{array}{r}4 \\
40 \\
38 \\
23 \\
14 \\
6 \\
6\end{array}$ & $\begin{array}{l}(4) \\
(37) \\
(31) \\
(22) \\
(11) \\
(4) \\
(3)\end{array}$ & $\begin{array}{r}3 \\
16 \\
15 \\
11 \\
10 \\
8 \\
12\end{array}$ & $\begin{array}{l}(3) \\
(15) \\
(13) \\
(10) \\
(8) \\
(5) \\
(6)\end{array}$ & $\begin{array}{r}1 \\
7 \\
10 \\
10 \\
8 \\
9 \\
8\end{array}$ & $\begin{array}{l}(1) \\
(6) \\
(7) \\
(7) \\
(6) \\
(7) \\
(5)\end{array}$ & $\begin{array}{r}1 \\
3 \\
4 \\
5 \\
6 \\
12 \\
16\end{array}$ & $\begin{array}{l}(1) \\
(2) \\
(3) \\
(3) \\
(4) \\
(9) \\
(10)\end{array}$ \\
\hline $\begin{array}{l}\text { Total } \\
\text { Average }\end{array}$ & 131 & $\underline{(112)}$ & $\overline{12}$ & $\overline{(10)}$ & $\underline{53}$ & $\underline{(39)}$ & $\overline{5}$ & $\overline{(4)}$ \\
\hline
\end{tabular}

* Figures in parentheses indicate patients with urethritis (urethral syndrome).

+ Figures in parentheses indicate patients with significant bacteriuria.

the calculated age-specific prevalence rates. Acute cases are three times as frequent as recurrent or chronic cases, and symptoms from the lower urinary tract exclusively (urethritis or urethral syndrome) are about 10 times as frequent as diseases involving the upper urinary tract. The prevalence rates did not vary definitely in women of different marital status. The seasonal variations for the recording of women with infectious symptoms without bacteriuria presented a peak in February (Fig. 2), since, as mentioned later, we must disregard the first two months of the year.

Of the 61 men with symptoms of urinary tract infection, $24(39 \%)$ had no growth of bacteria in the urine. The age distribution differed only slightly from that of women with the same entity. Eighteen men had urethritis and six showed signs of more widespread disease. The average prevalence rate for men with symptoms of infection without bacteriuria was about 2 per 1,000 adult males per year. Urethritis occurred more often in younger than in elderly males. Records of 10 of the 24 patients were made in the two coldest months of the year (January and February).

Three-quarters of the women with infectious symptoms without bacteriuria stated that previously they had suffered from similar symptoms, $8 \%$ were pregnant at the time of the examination, $80 \%$ were of child-bearing age, and $14 \%$ had undergone gynaecological surgery. The symptoms were almost identical to those observed in women with definite urinary tract infection. In $22 \%$ of the 129 women who underwent gynaecological examination abnormal conditions (fluor vaginalis, vaginitis, etc.) other than genital prolapse were found. Only $4 \%$ had proteinuria, and urine microscopy revealed pathological conditions considerably less often than in women with definite urinary tract infection (34\% leucocyturia and $13 \%$ haematuria).

\section{Symptoms and Doubtful Bacteriuria}

Sixty $(15 \%)$ of the women with symptoms of urinary tract infection and $3(5 \%)$ of the men had doubtful bacteriuria $(2,000-50,000 \mathrm{col} . / \mathrm{ml}$.). We found it advisable to treat this group separately. A total of 76 women showed doubtful results on culture from urine. The bacterial findings in these patients did not differ from the findings in women with significant 
bacteriuria. This indicates that patients with doubtful bacteriuria should not, as a matter of course, be classified as noninfected.

\section{Recurrent/Chronic Infection}

Out of 53 women and 13 men with signs of recurrent/ chronic pyelonephritis or cystopyelitis, $39(74 \%)$ and $8(62 \%)$, respectively, had significant bacteriuria. The age distribution and the age-specific prevalence rates for women are shown in Table VI. The average prevalence rate for women was 5 and for men about 1 per 1,000 per year. Of the 39 women with significant bacteriuria, $10(26 \%)$ had a previous history of abuse of phenacetin-containing drugs, as against only $3 \%$ of the remaining women with definite urinary tract infection. Thirtytwo per cent. of the 53 women had proteinuria, and in the 39 definitely infected women urine microscopy revealed leucocyturia more often than in the remaining 14 patients. The types of organism encountered in the 39 women with significant bacteriuria did not differ from those found in the remaining 184 definitely infected women in the study.

\section{Observation for Urinary Tract Disease}

The difficulties encountered when trying to establish a final and exact diagnosis in general practice are well known (Research Committee of the College of General Practitioners, 1958). In $81(14 \%)$ of the 571 women with urinary tract disease and in $20(12 \%)$ of the 170 men we had to be content with the diagnosis of " observation for urinary tract disease." In women, more than in men, the diagnostic uncertainty was due mainly to inadequate bacteriological tests.

\section{Urinary Calculi}

Urinary calculi were found in 31 men. Nineteen of these had ureterolithiasis, 10 had nephrolithiasis, and two had calculi in the bladder. In the group of 13 women with urolithiasis eight had nephrolithiasis and five ureterolithiasis. The age maximum for men is in the group aged 40 to 49 years and for women in the group aged from 50 to 59 years. The average prevalence rate for men is 3 patients per 1,000 per year and for women about 1 per 1,000 per year. The diagnosis of urolithiasis was in a few cases made exclusively on the clinical findings. Intravenous pyelography, however, was carried out in 41 of the 44 patients, and in 37 patients calculi or other pathological conditions were demonstrated.

\section{Gynaecological Disorders}

Of the total number of patients, 70 women presented with genital prolapse at the gynaecological examination. The age distribution and the age-specific prevalence rates are given in Table VII. In 27 women with symptoms from the lower

\begin{tabular}{l|l|l|l|l} 
TABLE VII.-Prevalence of Genital Prolapse and Prostatic Hypertrophy \\
\hline
\end{tabular}

\footnotetext{
* Figures in parentheses indicate patients with significant bacteriuria.
}

urinary tract without significant bacteriuria which developed shortly after operation for genital prolapse or surgery to the uterus, we interpreted the condition as a sequel from gynaecological surgery. None of these patients was younger than 30 years, and the prevalence rates per 1,000 females per year have been calculated as follows: $30-49$ years, 3 ; 50-69 years, 4 ; 70 years and over, 4

\section{Urogenital Tract Disease in the Male}

In 48 of the 170 men with urinary tract disease rectal examination showed prostatic hypertrophy. The age distribution and the calculated prevalence rates are given in Table VII. In the 39 non-infected patients the symptoms were characterized, as expected, by frequent and difficult micturition. Fifteen, mainly younger, men were classified as having prostatitis. The entity was rather diffuse, and no significant bacteriuria was found in any of these patients. Sequels of prostatectomy were found in eight men, in seven men a diagnosis of sphincter sclerosis was established during a stay in hospital, and four suffered from epididymitis.

\section{Other Urinary Tract Diseases}

Other renal or urinary tract diseases are very infrequent, and consequently the prevalence of these disorders cannot be calculated on the basis of the present study. It should be mentioned, however, that papilloma of the bladder was found in three women and one man and cancer of the bladder in one woman and one man. No cases of renal cancer were found in this material.

\section{Discussion}

Morbidity data collected in general practices will never provide a complete picture of the morbidity of the population. Hence the Sickness Survey of Denmark 1951-1954 (Danish National Morbidity Survey, 1960) indicated that only about $40 \%$ of patients with symptoms of renal or urinary tract diseases consult a doctor. On the other hand, general practice studies provide a suitable delimitation of the disease entities (General Register Office, 1958, 1962). Because of the considerable differences which were found between the eight general practices covered by the study-in respect of size, number of patients recorded, and their distribution in further detail-we wish to emphasize that data obtained from a single practice or from only a few practices cannot be expected to be representative and hence cannot permit more detailed conclusions concerning disease prevalence.

We found the prevalence of urinary tract infections in our females (20 patients per 1,000 per year) to correspond fairly well with British results, though the latter showed lower frequencies in elderly women than those found in our material (General Register Office, 1958, 1962 ; Fry et al., 1962 ; Loudon and Greenhalgh, 1962). Nevertheless, Sourander's (1966) study showed that even our fairly high prevalence rates underestimate considerably the actual frequency of urinary tract infection in elderly women. The age variations in the prevalence of urinary tract infection in women indicate that it is a question of fundamentally different entities in younger women of child-bearing age and in elderly women after the menopause. The frequent acute infections in young women are, most likely, correlated with sexual activity, pregnancies, and deliveries. From a minimum at about the time of the menopause the prevalence rises steadily with age-a result which might depend on the increasing frequency of degenerative and obstructing disorders in the urinary tract. The prevalence of urinary tract infections in the men of our series also corresponds fairly well with 
British findings. Probably the entities in younger and elderly men are different, and the higher prevalence of urinary tract infections in elderly men must be ascribed, in particular, to prostatic hypertrophy.

The seasonal variation found in urinary tract infections in women cannot be taken to indicate the seasonal variation of these diseases, since we have recorded the number of persons and not periods of ill-health. Even if the first two months of the year are disregarded, these variations, however, seem to indicate that there is a maximum during early summer and, presumably, also during autumn. Loudon and Greenhalgh (1962) found no seasonal relationship, whereas the limited study of Mou and Feldman (1961) indicated a higher frequency of bacteriuria during spring. Possible causes of this may be the inadequate way women of ten dress and seasonal variations, if any, in their sexual activity. In this connexion it should be mentioned that the seasonal variations in the birth curve in Denmark show a peak in March and April, corresponding to a time of conception in June and July the previous year.

The occurrence of $E$. coli in $70 \%$ and of Staph. saprophyticus in $14 \%$ of the urine specimens, with significant growth in the women, corresponds to the findings of Gallagher et al. (1965). Today there should be no doubt that in younger women definite urinary tract infections due to Staph. saprophyticus do occur. We have found that these infections are accompanied by leucocyturia and haematuria more often than other urinary tract infections. Significant growth of bacteria other than the two mentioned above, or mixed infections, must give rise to a suspicion of pathological changes in the urinary tract and lead to more detailed examination of the patient.

With respect to the men, we agree with McGeachie (1966) that demonstration of bacteria other than $E$. coli in the urine should lead to a complete urological examination, to disclose any urinary tract abnormalities. The difference in the bacteriological pattern found between the two sexes is most likely related to more frequent changes in the male urinary tract.

\section{Increasing Awareness}

During recent years clinicians and research workers have become increasingly aware of the fact that women may present lower urinary tract diseases with symptoms of urinary tract infection without bacteriuria. In general practice Gallagher ct al. (1965) found that only $59 \%$ of patients with symptoms appeared to be bacteriologically infected, whereas Mond et al. (1965) found $45 \%$ to be infected. Our 131 patients appear to correspond well to Moore and Hira's (1965) primary group of 182 women, and the age distribution and the percentage of patients with disorders confined exclusively to the lower urinary tract do not differ greatly in the two series. Similarly, on gynaecological examination of several women we found pathological conditions other than genital prolapse, and it must be assumed that the symptoms in these patients are largely caused by a primary disorder in the genital organs. Seasonal variations in the incidence of infectious symptoms without bacteriuria in women (resembling the variations in acute respiratory tract infections) might indicate that exposure to cold weather is a significant factor.

Women with symptoms of urinary tract infection without bacteriuria constitute a very heterogeneous group. The majority are younger women of child-bearing age with symptoms from the lower urinary tract (urethritis, urethral syndrome), and it must be presumed that sexual activity, pregnancies, and childbirth, as well as exposure to cold weather, exert an influence on the development of these cases. In a limited group the symptoms are due to a primary disorder in the genital organs. Finally, a number of elderly women with symptoms from the upper urinary tract are most likely to have a chronic infectious urinary tract disease, though significant bacteriuria may not be found on examination. Other authors' series may also include cases such as those which we decided to exclude because we interpreted them as sequels of gynaecological surgery or as the result of genital prolapse.

We found, as did Andersen (1966), that urolithiasis is about three times as frequent in men as in women, and the study carried out by Ahlgren and Lörstad (1965) showed-and our findings agree-that ureterolithiasis is predominant in men, as against nephrolithiasis in women.

The General Register Office $(1958,1962)$ presented the same average frequency of genital prolapse as that found by us, though the frequency increased steadily with age. The decrease in the prevalence in elderly women must be ascribed to the fact that we recorded mostly women with genital prolapse accompanied by urinary tract symptoms. Also, elderly women probably consult their doctor less frequently for complaints from a prolapse, partly because of their less active sexual life.

The average prevalence of prostatic hypertrophy found by us corresponds to Norwegian findings (Bentsen, 1966). Morbidity Statistics from General Practice (General Register Office, 1958, 1962) showed a somewhat lower prevalence in England, which might be explained by the fact that fewer patients underwent rectal examination, as this study did not aim primarily at recording the prevalence of urinary tract disorders.

Grants were received from a foundation established by Lundbeck and Co. Ltd. in support of research in general practice, and from King Christian X's Foundation.

Requests for reprints should be sent to Dr. Jens Steensberg, 1 Store Kongensgade, 1264 Copenhagen K, Denmark.

\section{REFERENCES}

Ahlgren, S.-A., and Lörstad, M. (1965). Acta Chirurgica Scandinavica, 130, 344 .

Andersen, D. A. (1966). Fournal of Oslo City Hospitals, 16, 101.

Bentsen, B. G. (1966). Tidsskrift for den Norske Lageforening, 86, 245

Danish National Morbidity Survey (1960). The Sickness Survey of Denmark 1951-1954. Copenhagen, Munksgaard.

Effersøe, P., and Jensen, E. (1963). Lancet, 1, 1342.

Fry, J., Dillane, J. B., Joiner, C. L., and Williams, J. D. (1962). Lancet, 1, 1318.

Gallagher, D. J A., Montgomerie, J. Z., and North, J. D. K. (1965). British Medical fournal, 1, 622 .

General Register Office (1958). Morbidity Statistics from General Practice, vol. 1. London, H.M.S.O.

General Register Office (1962). Morbidity Statistics from General Practice, vol. 3. London, H.M.S.O.

Loudon, I. S., and Greenhalgh, G. P. (1962). Lancet, 2, 1246.

McGeachie, J. (1966). British fournal of Urology, 38, 294.

Merritt, A. D., Sanford, J. P., and Durham, N. C. (1958). Fournal of Laboratory and Clinical Medicine, 52, 463.

Mond, N. C., Percival, A., Williams, J. D., and Brumftt, W. (1965). Lancet, i, 514.

Moore, T., and Hira, N. R. (1965). British fournal of Urology, 37, 25. Mou, T. W., and Feldman, H. A. (1961). Antimicrobial Agents and Chemotherapy, p. 109.

Research Committee of the College of General Practitioners (1958). fournal of the College of General Practitioners, 1, 107

Sourander, L. B. (1966). Annales Medicine Interne Fennise, 55, Suppl. No. 45 . 